\title{
SOIL QUALITY INDEX ANALYSIS IN EFFORTS TO OVERCOME LAND DEGRADATION IN NGANJUK REGENCY
}

\section{ANALISIS INDEKS KUALITAS TANAH DALAM UPAYA MENGATASI DEGRADASI LAHAN DI KABUPATEN NGANJUK}

\author{
Dyah Nursita Utami ${ }^{1}$ \\ ${ }^{1}$ Pusat Teknologi Reduksi Risiko Bencana (PTRRB) - BPPT \\ Gedung 820, Geostech, Komplek Puspiptek, Serpong, Kota Tangerang Selatan \\ e-mail: dyah.nursita@bppt.go.id
}

\begin{abstract}
Soil quality is ability of soil to preserve the productivity of pants, preserve maintain water supplies, and support human activities. Soil quality assessment results can be used as a recommendation in addressing land degradation. The soil quality cannot be directly measured therefore physical, chemical and biological indicators collectively are determined which influence the soil quality called minimum data set (MDS). A study and experimental analysis was conducted in August - November, 2019. The descriptive study was done in some land units in Nganjuk Regency by measuring its soil index quality using Mausbach and Seybold (1998) criteria which has been modified by Partoyo (2005). The soil quality index was analyzed using function that represented most of the soil. The soil samples were taken by purposive sampling and the texture, volume weight, porosity, C-organic, $\mathrm{pH}$, P-available, $K$-exchangeable, $\mathrm{N}$-total and rooting depth were analyzed in laboratories. Soil quality index values ranged between 0-1. The higher index value indicates better quality. The analysis result of selected soil functions (MDS) and MDS scores were than summed to determine the value of the soil quality index (SQI). The study concludes that several land units in Ngluyu, Wilangan, and Tanjunganom Districts that had low soil quality (IKT $=0.2399-0.3869)$. Meanwhile, the land units in Bagor District have very good soil quality criteria $(I K T=0.8671)$.
\end{abstract}

Keywords: soil quality index, land degradation, minimum data set, nganju.

\begin{abstract}
Abstrak
Kualitas tanah adalah kemampuan tanah untuk berfungsi mempertahankan produktivitas tanaman, mempertahankan dan menjaga ketersediaan air serta mendukung kegiatan manusia. Hasil penilaian kualitas tanah dapat digunakan sebagai rekomendasi dalam mengatasi degradasi lahan. Kualitas tanah tidak dapat diukur secara langsung, sehingga perlu ditentukan indikator fisik, kimia, dan biologi yang secara bersama-sama memberikan pengukuran menyeluruh kualitas tanah, disebut minimum data set (MDS). Suatu studi lapangan dan analisis laboratorium telah dilakukan pada bulan Agustus - November 2019. Penelitian deskriptif ini dilaksanakan terhadap beberapa unit lahan yang ada di Kabupaten Nganjuk. Menghitung nilai indeks kualitas tanah menggunakan kriteria Mausbach dan Seybold (1998) yang telah dimodifikasi Partoyo (2005). Indeks kualitas tanah dianalisis menggunakan indikator-indikator yang paling mewakili fungsi-fungsi tanah. Pengambilan sampel tanah menggunakan metode purposive sampling, selanjutnya dianalisis di laboratorium terhadap tekstur, berat volume, porositas, C-organik, $\mathrm{pH}, \mathrm{P}$ tersedia, K-tertukar, $\mathrm{N}$-total dan diukur kedalaman perakaran. Nilai indeks kualitas tanah berkisar antara $0-1$, semakin tinggi nilai indeks menunjukkan kualitas semakin baik. Hasil analisis fungsi tanah terpilih (minimum data set/MDS) dan skoring MDS dilakukan penjumlahan untuk mengetahui nilai indeks kualitas tanah (IKT). Kesimpulan penelitian menghasilkan beberapa unit lahan di Kecamatan Ngluyu, Wilangan, dan Tanjunganom mempunyai kualitas tanah rendah (IKT = $0,2399-0,3869$ ). Sedangkan unit lahan di Kecamatan Bagor mempunyai kualitas tanah dengan kriteria sangat baik $(\mathrm{IKT}=0,8671)$.
\end{abstract}

Kata kunci: indeks kualitas tanah, degradasi lahan, minimum data set, nganjuk. 


\section{PENDAHULUAN}

\subsection{Latar Belakang}

Berdasarkan Statistik Daerah Kabupaten Nganjuk (2019) sektor pertanian mempunyai kontribusi yang sangat berarti pada perekonomian di wilayah Kabupaten Nganjuk. Hal ini tercermin pada pembentukan Produksi Domestik Regional Bruto (PDRB) yang menunjukkan bahwa sektor pertanian sebagai penyumbang kedua setelah sektor Perdagangan.

Salah satu faktor penentu tinggi rendahnya produksi pertanian suatu daerah adalah luas lahan pertaniannya. Di tahun 2019, Kabupaten Nganjuk dengan luas lahan $122.433 \mathrm{Ha}$, menurut penggunaan lahannya diketahui bahwa 42.893,0 $\mathrm{Ha}$ merupakan lahan pertanian sawah, 44.301,2 Ha lahan pertanian bukan sawah dan sisanya seluas 35.238,8 Ha merupakan lahan bukan pertanian (Dinas Pertanian Kabupaten Nganjuk, 2019).

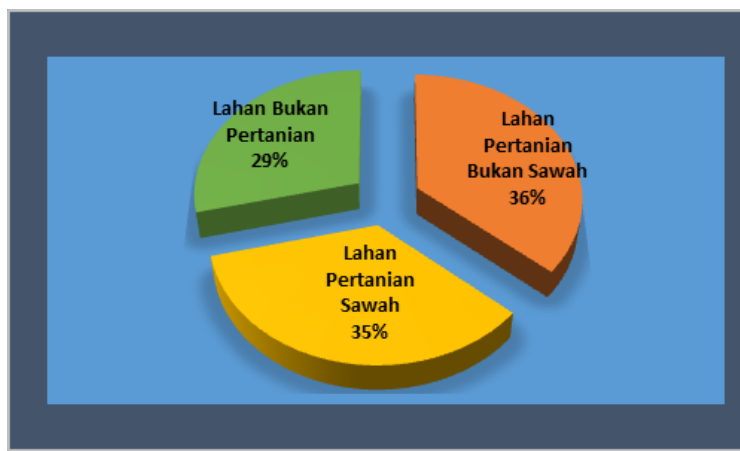

Gambar 1. Porsentase Penggunaan Lahan di Nganjuk Tahun 2019 (Sumber : Dinas Pertanian Kabupaten Nganjuk)

Berdasarkan data dari Dinas Pertanian Kabupaten Nganjuk (2019), produksi padi pada tahun 2019 mengalami penurunan dari tahun sebelumnya, yaitu 567.760 ton pada tahun 2018 menjadi 538.527 ton pada tahun 2019, atau turun sekitar $5,15 \%$. Pada Tahun 2019, ada 3 komoditi yang mengalami kenaikan yaitu jagung, ketela pohon dan ketela rambat sedangkan komoditas palawija yang lain seperti kacang tanah, dan kedelai mengalami penurunan di bandingkan 2018.

Salah satu penyebab terjadinya penurunan produktivitas di Kabupaten Nganjuk adalah terjadinya degradasi lahan. Proses penurunan produktivitas lahan, baik yang sifatnya sementara maupun tetap biasa disebut dengan degradasi lahan. Menurut Wahyunto dan $\mathrm{Ai}$ Dariah (2014) lahan terdegradasi dalam definisi lain sering disebut lahan tidak produktif, lahan kritis, atau lahan tidur yang dibiarkan terlantar tidak digarap dan umumnya ditumbuhi semak belukar. Sedangkan dari sektor pertanian mendefinisikan degradasi lahan sebagai proses penurunan produktivitas lahan yang sifatnya sementara maupun tetap, dicirikan dengan penurunan sifat fisik, kimia dan biologi tanah (Shresta, 1995; Singer, 2006; Sitorus, 2011). Akibat lanjut dari proses degradasi lahan adalah timbulnya areal-areal yg tidak produktif yang disebut lahan kritis (Dariah et al. 2004; Kurnia 2010).

Pada dasarnya degradasi lahan disebabkan karena adanya penggunaan dan/atau pengelolaan lahan yang kurang tepat. Pada lahan pertanian (khususnya pertanian di lahan kering), degradasi lahan utamanya terjadi karena adanya erosi tanah yang dipercepat, penggunaan mesin-mesin pertanian, dan pemakaian bahan kimia pertanian yang berlebihan.

Lahan terdegradasi bukan saja merupakan lahan yang tidak produktif, menurunkan produktivitas lahan, tetapi juga dapat menjadi sumber bencana, mulai dari kekeringan, banjir, tanah longsor, sampai kebakaran yang bisa berdampak terhadap terjadinya percepatan pemanasan global. Akibat negatif adanya lahan terdegradasi tidak hanya dirasakan di lokasi di mana lahan terdegradasi berada, tetapi menyebar sangat jauh dan luas.

Salah satu upaya yang dapat dilakukan untuk mengetahui suatu lahan mengalami degradasi adalah dilakukannya analisis indeks kualitas tanah. Analisis indeks kualitas tanah dimaksudkan untuk mengetahui kondisi fisik, kimia dan biologi tanah. Keadaan fisika tanah meliputi kedalaman efektif, tekstur, struktur, kelembaban dan tata udara tanah. Keadaan kimia tanah meliputi reaksi tanah ( $\mathrm{pH}$ tanah), KTK, KB, bahan organik, banyaknya unsur hara, cadangan unsur hara dan ketersediaan terhadap pertumbuhan tanaman. Sedangkan biologi tanah antara lain meliputi aktivitas mikrobia perombak bahan organik dalam proses humifikasi dan pengikatan nitrogen udara.

Indikator kualitas tanah adalah sifat, karakteristik atau proses fisika, kimia dan biologi tanah yang dapat menggambarkan kondisi tanah (SQI, 2001). Karlen et al. (1997) mengusulkan bahwa pemilihan indikator kualitas tanah harus mencerminkan kapasitas tanah untuk menjalankan fungsinya. Berdasarkan fungsi tanah yang hendak dinilai kemudian dipilih beberapa indikator yang sesuai. Menurut Mausbach dan Seybold (1998), pemilihan indikator berdasarkan pada konsep minimum data set (MDS), yaitu sesedikit mungkin tetapi dapat memenuhi kebutuhan. 


\subsection{Tujuan Penelitian}

Tujuan dari penelitian ini adalah 1) mengetahui indeks tanah; 2) mengetahui parameter sifat tanah yang berpengaruh dalam memperbaiki degradasi lahan ; 3) memperoleh rekomendasi yang tepat dalam upaya penanganan degradasi lahan di Kabupeten Nganjuk

\section{METODOLOGI PENELITIAN}

\subsection{Lokasi dan Waktu Kajian}

Penelitian ini dilaksanakan di Kabupaten Nganjuk pada bulan Agustus - November 2019. Lokasi pengambilan sampel tersebar di seluruh kecamatan di Kabupaten Nganjuk.

\subsection{Alat dan Bahan}

Alat yang digunakan dalam penelitian ini meliputi: peralatan dasar survei tanah (ring sampel, meteran, meteran profil, cangkul, GPS (Global Positioning System), kompas, Munsel soil colour chart, Form Isian Kualitas Lahan, kamera, dan seperangkat komputer.

Bahan yang diperlukan dalam pembuatan peta survei Kabupaten Nganjuk, diperlukan peta-peta dasar sebagai berikut:

1. Peta jenis tanah

2. Peta jenis penggunaan lahan

3. Peta topografi

4. Peta administrasi

Hasil overlay peta-peta diatas menjadi peta satuan lahan (SPL) yang akan di analisis secara spasial untuk menentukan titik samplingnya.

\subsection{Metodologi Penelitian}

Metode penelitian dalam kajian di Kabupaten Nganjuk adalah sebagai berikut:

1. Koordinasi dengan instansi terkait

Dalam hal ini koordinasi dilakukan dengan Badan Perencanaan dan Pembangunan Daerah Kabupaten Nganjuk, Dinas Pertanian Kabupaten Nganjuk, dan Badan Penanggulangan Bencana Daerah Kabupaten Nganjuk. Koordinasi ini akan memudahkan pemetaan potensi lahan berdasarkan data yang ada.

\section{Pengumpulan data sekunder}

Pengumpulan data sekunder ini meliputi studi pustaka data pendukung serta peta-peta dasar yang diperlukan dalam pembuatan pata SPL.

\section{Pengumpulan data primer}

Metode pengumpulan data secara primer dilakukan melalui survei lapangan dengan peta SPL. Survei lapangan meliputi pengamatan biofisik lahan, pengambilan sampel tanah, serta wawancara kepada petani jika memungkinkan.

4. Analisis laboratorium

Setelah diperoleh sampel tanah disetiap titik-titik pengamatan, maka dilakukan analisis laboratorium untuk setiap parameter kesuburan tanah. Analisis tanah dilakukan di Laboratorium ICBB (Indonesian Center For Biodiversity and Biotechnology) Bogor.

5. Analisis data dan Interpretasi

Setelah hasil laboratorium diketahui, maka dilakukan analisis serta interpretasi dari hasil pengamatan dan hasil laboratorium. Indeks Kualitas Tanah dihitung berdasarkan kriteria Mausbach dan Seybold (1998) yang dimodifikasi oleh Partoyo (2005). Analisis indeks kualitas tanah dilakukan berdasarkan data hasil analisis laboratorium terhadapi indikator kualitas tanah yang dipilih, yaitu: $\mathrm{pH}$ $\left(\mathrm{H}_{2} \mathrm{O}\right)$, C-organik, $\mathrm{N}$-total, P-tersedia, Ktertukar, kedalaman perakaran, ukuran fraksi (tekstur), berat volume (bulk density), porositas (Tabel 1).

Menurut Partoyo (2005), langkah-langkah perhitungan indeks dilakukan dengan cara sebagai berikut:

a. Indeks bobot dihitung dengan mengalikan bobot fungsi tanah (bobot 1) dengan bobot medium perakaran (bobot 2) dengan bobot kedalaman perakaran (bobot 3). Misalnya, indeks bobot untuk porositas diperoleh dengan mengalikan 0,40 (bobot 1) dengan 0,33 (bobot 2) dengan 0,60 (bobot 3), dan hasilnya sama dengan 0,080 .

b. Skor dihitung dengan membandingkan data pengamatan dari indikator tanah dan fungsi penilaian. Skor berkisar dari 0 untuk kondisi buruk dan 1 untuk kondisi baik. Penetapan skor dapat melalui interpolasi atau persamaan linier sesuai dengan kisaran yang ditetapkan berdasar harkat atau berdasarkan data yang diperoleh. Fungsi Scoring Linear sebagai berikut:

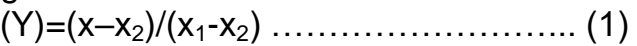

$$
\begin{aligned}
& (Y)=1-\left(x-x_{2}\right) /\left(x 1-x_{2}\right) \ldots \ldots \ldots \ldots \ldots \ldots(2)
\end{aligned}
$$

dimana, $Y$ adalah skor linier, $x$ adalah nilai sifat-sifat tanah, $x_{2}$ adalah nilai batas atas dan $x_{1}$ nilai batas bawah.

c. Indeks Kualitas Tanah dihitung dengan mengalikan indeks bobot dan skor dari indikator. Penilaian kualitas tanah menggunakan persamaan indeks kualitas tanah (Liu et al., 2014) yaitu:

$$
\text { IKT }=\sum \mathrm{Wi} \times \mathrm{Si}
$$

dimana: IKT = indeks kualitas tanah,

$\mathrm{Si}=$ skor pada indikator terpilih, $\mathrm{Wi}=$ indeks bobot, $\mathrm{n}=$ jumlah indikator kualitas tanah. Selanjutnya nilai indeks kualitas tanah dikatagorikan dalam lima kelas kriteria seperti terdapat pada Tabel 2. 
Tabel 1. Modifikasi Indikator dan Bobot Indeks Kualitas Tanah

\begin{tabular}{|c|c|c|c|c|c|c|}
\hline Fungsi Tanah & Bobot & Indikator Tanah & Satuan & Bobot & Bobot & Indeks Bobot \\
\hline & 1 & & & 2 & 3 & $(1 \times 2 \times 3)$ \\
\hline \multirow{13}{*}{$\begin{array}{l}\text { Melestarikan } \\
\text { aktivitas biologi }\end{array}$} & \multirow{13}{*}{0,4} & A. Media Perakaran & & 0,33 & & \\
\hline & & Kedalaman perakaran & $\mathrm{cm}$ & & 0,6 & 0,0792 \\
\hline & & Berat volume & $\mathrm{g} \mathrm{cm}-1$ & & 0,4 & 0,0528 \\
\hline & & B. Kelengasan & & 0,33 & & \\
\hline & & Porositas & $\%$ & & 0,2 & 0,0264 \\
\hline & & C-Organik & $\%$ & & 0,4 & 0,0528 \\
\hline & & Debu+liat & $\%$ & & 0,4 & 0,0528 \\
\hline & & C. Keharaan & & 0,33 & & \\
\hline & & $\mathrm{pH}$ & & & 0,1 & 0,0132 \\
\hline & & P-tersedia & $\mathrm{ppm}$ & & 0,2 & 0,0264 \\
\hline & & K-tertukar & $\mathrm{cmol} \mathrm{kg-1}$ & & 0,2 & 0,0264 \\
\hline & & C-organik & $\%$ & & 0,3 & 0,0396 \\
\hline & & N-total & $\%$ & & 0,2 & 0,0264 \\
\hline \multirow{3}{*}{$\begin{array}{c}\text { Pengaturan dan } \\
\text { penyaluran air }\end{array}$} & \multirow{3}{*}{0,3} & Debu+liat & $\%$ & 0,6 & & 0,18 \\
\hline & & Porositas & $\%$ & 0,2 & & 0,06 \\
\hline & & Berat volume & $\mathrm{g} \mathrm{cm}-1$ & 0,2 & & 0,06 \\
\hline \multirow{5}{*}{$\begin{array}{l}\text { Penyaring dan } \\
\text { penyangga }\end{array}$} & \multirow{5}{*}{0,3} & Debu+liat & $\%$ & 0,6 & & 0,18 \\
\hline & & Porositas & $\%$ & 0,1 & & 0,03 \\
\hline & & Proses mikrobiologis & & 0,3 & & 0,09 \\
\hline & & C-Organik & $\%$ & & 0,5 & 0,045 \\
\hline & & N-total & $\%$ & & 0,5 & 0,045 \\
\hline
\end{tabular}

Sumber: Mausbach dan Seybold (1998 dalam Partoyo, 2005)

Tabel 2. Kriteria Kualitas Tanah Berdasarkan Nilai Indeks Kualitas Tanah (IKT)

\begin{tabular}{l|l|l}
\hline No & \multicolumn{1}{|c}{ Kelas Nilai IKT } & \multicolumn{1}{|c}{$\begin{array}{c}\text { Kriteria Kualitas } \\
\text { Tanah }\end{array}$} \\
\hline 1 & $0,80-1,00$ & Sangat baik (SB) \\
2 & $0,60-0,79$ & Baik (B) \\
3 & $0,40-0,59$ & Sedang (S) \\
4 & $0,20-0,39$ & Rendah (R) \\
5 & $0,00-0,19$ & Sangat rendah (SR) \\
\hline
\end{tabular}

Sumber : Partoyo, 2005

6. Evaluasi dan rekomendasi
Dari hasil analisis dan interpretasi data yang telah diperoleh maka dilakukan evalusi dan rekomendasi sesuai dengan tujuan kajian di Kabupaten Nganjuk.

\section{HASIL DAN PEMBAHASAN}

\subsection{Hasil dan Analisis}

Hasil analisis sifat fisika tanah, kimia tanah dan kedalaman perakaran di Kabupaten Nganjuk disajikan pada Tabel 3 dan Tabel 4:

Tabel 3. Analisis Laboratorium Sifat Fisika, Sifat Kimia Tanah dan Kedalaman Perakaran

\begin{tabular}{l|c|c|c|c|c|c|c|c|c}
\hline \multirow{2}{*}{$\begin{array}{l}\text { Sifat fisika, kimia } \\
\text { tanah dan kedalaman } \\
\text { perakaran }\end{array}$} & \multirow{2}{*}{ Satuan } & \multicolumn{7}{|c|}{ Unit Lahan (UL) } \\
\cline { 3 - 9 } & & UL 1 & UL 2 & UL 3 & UL 4 & UL 5 & UL 6 & UL 7 & UL 8 \\
\hline Kedalaman perakaran & $\mathrm{cm}$ & 50 & 50 & 50 & 40 & 50 & 50 & 50 & 50 \\
Tekstur Tanah & & & & & & & & & \\
- Pasir & $\%$ & 26 & 16 & 29 & 17 & 39 & 16 & 12 & 27 \\
- Debu & $\%$ & 27 & 14 & 28 & 34 & 15 & 26 & 31 & 24 \\
- Liat & $\%$ & 47 & 70 & 43 & 48 & 46 & 58 & 58 & 49 \\
Berat Volume & $\mathrm{g} \mathrm{cm}$ & 1,12 & 1,15 & 1,19 & 1,02 & 1,16 & 1,19 & 1,07 & 1,06 \\
Porositas & $\%$ & 48,78 & 47,62 & 46,66 & 51,76 & 39,51 & 42,56 & 49,89 & 47,25 \\
pH H H & & 6,09 & 7,47 & 5,99 & 7,29 & 7,66 & 7,66 & 7,77 & 7,76 \\
N-total & $\%$ & 0,15 & 0,24 & 0,07 & 0,10 & 0,11 & 0,22 & 0,13 & 0,14 \\
P-tersedia & $\mathrm{Ppm}$ & 11,60 & 161,66 & 7,68 & 58,16 & 15,58 & 81,46 & 120,41 & 96,82 \\
\hline
\end{tabular}




\begin{tabular}{l|c|c|c|c|c|c|c|c|c}
\hline K-tertukar & $\mathrm{cmol} \mathrm{kg}^{-1}$ & 0,29 & 1,35 & 0,05 & 0,55 & 0,04 & 0,15 & 0,49 & 0,42 \\
C-organik & $\%$ & 1,86 & 3,59 & 1,10 & 1,20 & 1,57 & 3,4 & 1,88 & 1,41 \\
\hline
\end{tabular}

Sumber : Hasil analisis laboratorium (2019)

Tabel 4. Analisis Laboratorium Sifat Fisika, Sifat Kimia Tanah dan Kedalaman Perakaran

\begin{tabular}{|c|c|c|c|c|c|c|c|c|c|}
\hline \multirow{2}{*}{$\begin{array}{l}\text { Sifat fisika, kimia } \\
\text { tanah dan kedalaman } \\
\text { perakaran }\end{array}$} & \multirow{2}{*}{ Satuan } & \multicolumn{8}{|c|}{ Unit Lahan (UL) } \\
\hline & & UL 9 & UL 10 & UL 11 & $\begin{array}{l}\text { UL } \\
12\end{array}$ & UL 13 & UL 14 & UL 15 & UL 16 \\
\hline $\begin{array}{l}\text { Kedalaman perakaran } \\
\text { Tekstur Tanah }\end{array}$ & $\mathrm{cm}$ & 50 & 50 & 25 & 50 & 50 & 40 & 75 & 75 \\
\hline - Pasir & $\%$ & 35 & 20 & 23 & 10 & 22 & 21 & 50 & 18 \\
\hline - Debu & $\%$ & 31 & 29 & 17 & 36 & 49 & 35 & 26 & 26 \\
\hline - Liat & $\%$ & 34 & 51 & 60 & 54 & 30 & 44 & 24 & 55 \\
\hline Berat Volume & $\mathrm{g} \mathrm{cm}^{-3}$ & 1,08 & 1,09 & 1,09 & 1,13 & 1,12 & 1,18 & 1,06 & 1,12 \\
\hline Porositas & $\%$ & 49,17 & 47,66 & 48,96 & 49,87 & 49,63 & 48,58 & 43,21 & 50,27 \\
\hline $\mathrm{pH} \mathrm{H} \mathrm{H}_{2} \mathrm{O}$ & & 6,97 & 7,09 & 6,76 & 6,89 & 7,48 & 8,29 & 7,60 & 8,20 \\
\hline N-total & $\%$ & 0,09 & 0,07 & 0,12 & 0,19 & 0,19 & 0,07 & 0,11 & 0,14 \\
\hline P-tersedia & Ppm & 117,62 & 143,23 & 208,61 & 52,57 & 106,92 & 36,98 & 60,93 & 88,97 \\
\hline K-tertukar & $\mathrm{cmol} \mathrm{kg}^{-1}$ & 0,23 & 0,26 & 0,55 & 0,18 & 0,40 & 0,12 & 0,76 & 0,84 \\
\hline C-organik & $\%$ & 1,13 & 1,00 & 1,16 & 2,48 & 2,57 & 0,66 & 1,47 & 2,46 \\
\hline
\end{tabular}

Sumber : Hasil analisis laboratorium (2019)

Hasil analisis sifat fisika tanah, kimia tanah dan kedalaman perakaran di Kabupaten Nganjuk menunjukkan keberagaman dari unit lahan 1 sampai unit lahan 16. Perbedaan nilai dari sifat-sifat tanah di Kabupaten Nganjuk di pengaruhi oleh beberapa faktor seperti topografi wilayah, jenis tanah, pola iklim dan pola penggunaan lahan.

Kedalaman perakaran tanah di Kabupaten Nganjuk tergolong baik untuk mendukung sektor pertanian, karena mempunyai kisaran antara $25 \mathrm{~cm}-75 \mathrm{~cm}$. Secara umum tanah tanah di Kabupaten Nganjuk mempunyai fraksi debu lebih tinggi dibandingkan dengan fraksi pasir dan liat. Kandungan fraksi debu antara $67,76 \%$ hingga $98,38 \%$, sehingga berdasarkan kriteria segitiga tekstur, tanah tanah di Kabupaten Nganjuk digolongkan sebagai tanah yang mempunyai tekstur lempung berdebu hingga lempung liat berdebu.

Berat volume (BV) tanah merupakan salah satu sifat fisik tanah yang paling sering ditentukan, karena keterkaitannya yang erat dengan kemudahan penetrasi akar di dalam tanah, drainase dan aerasi tanah, serta sifat fisik tanah lainnya. Pada tanah yang mudah mengembang dan mengerut, BV berubah-ubah seiring dengan berubahnya kadar air tanah (Agus et al, 2006). Berat volume di Kabupaten Nganjuk menunjukkan nilai yang berkisar antara $1,02 \mathrm{gr} / \mathrm{cm}^{3}$ hingga $1,19 \mathrm{gr} / \mathrm{cm}^{3}$.

Menurut Jocenei et al (2020) ruang pori total adalah volume dari tanah yang ditempati oleh udara dan air. Persentase volume ruang pori total disebut porositas. Tanah dengan tekstur halus mempunyai kisaran ukuran dan bentuk partikelnya yang luas. Hal ini telah ditekankan bahwa tanah permukaan yang berpasir mempunyai porositas kecil daripada tanah liat. Berarti bahwa tanah pasir mempunyai volume yang lebih sedikit ditempati oleh ruang pori. Ruang pori total pada tanah pasir mungkin rendah tetapi mempunyai proporsi yang besar yang disusun daripada komposisi pori-pori yang besar yang sangat efisien dalam pergerakan udara dan airnya. Persentase volume yang dapat terisi oleh poripori kecil pada tanah pasir rendah yang menyebabkan kapasitas menahan airnya rendah. Sebaliknya tanah-tanah permukaan dengan tekstur halus memiliki ruang pori total lebih banyak dan proporsinya relatif besar yang disusun oleh pori kecil. Akibatnya adalah tanah mempunyai kapasitas menahan air yang tinggi. Ruang pori total di lokasi studi bervariasi antara $39.51 \%$ yang terindentifikasi di Kecamatan Lengkong hingga yang tertinggi $51,76 \%$ teridentifikasi di Kecamatan Ngluyu.

Reaksi tanah adalah suatu ciri atau parameter yang digunakan untuk menunjukkan keadaan masam - basa dalam tanah. Kondisi $\mathrm{pH}$ tanah hasil analisis laboratorium di 16 lokasi menunjukkan kondisi $\mathrm{pH}$ tanah yang bervariasi antara 6,09 hingga yang tertinggi mendekati netral dengan $\mathrm{pH} 8,29$. Berdasarkan kriteria kualitas kesuburan tanah, $\mathrm{pH}$ tanah di lahan di wilayah Kabupaten Nganjuk relatif netral.

Kadar $\mathrm{N}$ total tanah wilayah Kabupaten Nganjuk berkisar antara 0,07\% hingga 0,24\%. Berdasarkan kriteria kesuburan tanah kandungan $\mathrm{N}$ total tanah dalam kategori bervariasi dari sangat rendah hingga tinggi. Kandungan terendah terdapat di wilayah Kecamatan Wilangan dan Kecamatan Ngluyu dan kandungan tertinggi berada di wilayah Kecamatan Bagor.

Kandungan $\mathrm{P}_{2} \mathrm{O}_{5}$ tersedia bervariasi antara $7,68 \mathrm{mg} / 100 \mathrm{~g}$ hingga 208,61 ppm. Berdasarkan kriteria kelas kualitas kesuburan tanah, rentang nilai tersebut termasuk dalam 
kualitas yang sedang hingga sangat tinggi. Perbedaan kandungan $\mathrm{P}_{2} \mathrm{O}_{5}$ dalam tanah tentunya tergantung dari bahan induk pembentuk tanah yang berbeda antara yang satu dengan yang lainnnya. Kandungan yang tinggi ini bisa berasal dari bahan batuan pembentuk phospat yang tinggi diwilayah tersebut. Kandungan terendah terdapat di wilayah Kecamatan Wilangan dan kandungan tertinggi berada di wilayah Kecamatan Ngluyu. Sedangkan kadar $\mathrm{K}_{2} \mathrm{O}$ tertukar bervariasi antara $0,04-1,35 \mathrm{cmol} \mathrm{kg}{ }^{-1}$, berdasarkan kriteria kelas kualitas kesuburan tanah mempunyai kualitas kandungan yang rendah.

Kandungan bahan C-organik bervariasi antara 0,66 \% hingga 3,41\%. Berdasarkan kriteria kelas kualitas kesuburan tanah, rentang nilai tersebut mempunyai kualitas kandungan $\mathrm{C}$ organik dari rendah hingga sangat tinggi. Kandungan terendah terdapat di wilayah Kecamatan Ngluyu dan kandungan tertinggi berada di wilayah Kecamatan Bagor.

\subsection{Indeks Kualitas Tanah dan Hubungannya Dengan Fungsi Tanah}

Kualitas tanah ditentukan oleh kapasitasnya untuk berfungsi dalam tata guna lahan dan batas ekosistem, dan menunjukkan produktivitas biologis dan pelestarian kualitas lingkungan, serta kesehatan tumbuhan, hewan, dan manusia, termasuk kemampuannya untuk menyangga polutan, seperti pertanian. dan bahan kimia industri (Bünemann et al., 2018).

Kualitas tanah diukur berdasarkan pengamatan kondisi dinamis indikator-indikator kualitas tanah. Pengukuran indikator kualitas tanah menghasilkan indeks kualitas tanah. Indeks kualitas tanah merupakan indeks yang dihitung berdasarkan nilai dan bobot tiap indikator kualitas tanah. Indikator-indikator kualitas tanah dipilih dari sifat-sifat yang menunjukkan kapasitas fungsi tanah.

\subsubsection{Melestarikan Aktivitas Biologi}

Tabel 5. Hasil Analisis Indeks Kualitas Tanah Berdasarkan Fungsi Tanah untuk Melestarikan Aktifitas Biologi

\begin{tabular}{l|c|c|c|c|c|c|c|c}
\hline \multirow{2}{*}{ Indikator Penilaian } & \multicolumn{7}{c}{ Indeks Kualitas Tanah (IKT) } \\
\cline { 2 - 9 } & UL 1 & UL 2 & UL 3 & UL 4 & UL 5 & UL 6 & UL 7 & UL 8 \\
\hline $\begin{array}{l}\text { A. Media Perakaran } \\
\quad \text { Kedalaman perakaran }\end{array}$ & 0,0396 & 0,0396 & 0,0396 & 0,0528 & 0,0396 & 0,0396 & 0,0396 & 0,0396 \\
$\quad$ Berat volume & 0,0185 & 0,0363 & 0,0139 & 0,0251 & 0,0158 & 0,0389 & 0,0310 & 0,0224 \\
\hline $\begin{array}{l}\text { B. Kelengasan } \\
\quad \text { Porositas }\end{array}$ & 0,0036 & 0,0221 & 0,0049 & 0,0019 & 0,0091 & 0,0191 & 0,0234 & 0,0045 \\
$\quad$ C-Organik & 0,0262 & 0,0542 & 0,0384 & 0,0368 & 0,0309 & 0,0512 & 0,0269 & 0,0334 \\
$\quad$ Debu+liat & 0,0053 & 0,0563 & 0,0079 & 0,0018 & 0,0167 & 0,0563 & 0,0607 & 0,0062 \\
\hline C. Keharaan & & & & & & & & \\
pH & 0,0084 & 0,0109 & 0,0088 & 0,0031 & 0,0015 & 0,0117 & 0,0122 & 0,0011 \\
P-tersedia & 0,0262 & 0,0200 & 0,0267 & 0,0200 & 0,0257 & 0,0094 & 0,0146 & 0,0149 \\
K-tertukar & 0,0197 & 0,0361 & 0,0264 & 0,0125 & 0,0267 & 0,0028 & 0,0122 & 0,0161 \\
C-organik & 0,0197 & 0,0407 & 0,0288 & 0,0276 & 0,0232 & 0,0384 & 0,0202 & 0,0251 \\
N-total & 0,0259 & 0,0015 & 0,0267 & 0,0264 & 0,0263 & 0,0013 & 0,0003 & 0,0260 \\
\hline \multicolumn{1}{|c|}{ Total } & 0,1931 & 0,3178 & 0,2222 & 0,2080 & 0,2154 & 0,2688 & 0,2411 & 0,1893 \\
\hline
\end{tabular}

Sumber : Hasil Analisis (2020)

Tabel 6. Hasil Analisis Indeks Kualitas Tanah Berdasarkan Fungsi Tanah untuk Melestarikan Aktifitas Biologi (lanjutan)

\begin{tabular}{l|c|c|c|c|c|c|c|c}
\hline \multirow{2}{*}{ Indikator Penilaian } & \multicolumn{7}{|c}{ Indeks Kualitas Tanah (IKT) } \\
\cline { 2 - 8 } & UL 9 & UL 10 & UL 11 & UL 12 & UL 13 & UL 14 & UL 15 & UL 16 \\
\hline A. Media Perakaran & & & & & & & & \\
$\quad$ Kedalaman perakaran & 0,0396 & 0,0396 & 0,0726 & 0,0396 & 0,0396 & 0,0528 & 0,0066 & 0,0726 \\
$\quad$ Berat volume & 0,0211 & 0,0205 & 0,0205 & 0,0350 & 0,0185 & 0,0145 & 0,0224 & 0,0343 \\
\hline B. Kelengasan & & & & & & & & \\
$\quad$ Porositas & 0,0034 & 0,0043 & 0,0035 & 0,0234 & 0,0032 & 0,0038 & 0,0069 & 0,0236 \\
$\quad$ C-Organik & 0,0379 & 0,0400 & 0,0374 & 0,0365 & 0,0149 & 0,0454 & 0,0325 & 0,0362 \\
$\quad$ Debu+liat & 0,0132 & 0,0000 & 0,0018 & 0,0616 & 0,0009 & 0,0009 & 0,0264 & 0,0537 \\
\hline C. Keharaan & & & & & & & & \\
pH & 0,0045 & 0,0040 & 0,0055 & 0,0083 & 0,0023 & 0,0013 & 0,0018 & 0,0141 \\
P-tersedia & 0,0122 & 0,0088 & 0,0002 & 0,0056 & 0,0136 & 0,0228 & 0,0197 & 0,0104 \\
K-tertukar & 0,0214 & 0,0206 & 0,0125 & 0,0036 & 0,0167 & 0,0245 & 0,0067 & 0,0220 \\
C-organik & 0,0284 & 0,0300 & 0,0281 & 0,0274 & 0,0112 & 0,0341 & 0,0244 & 0,0271 \\
N-total & 0,0265 & 0,0267 & 0,0262 & 0,0010 & 0,0254 & 0,0267 & 0,0263 & 0,0004 \\
\hline
\end{tabular}




\begin{tabular}{c|c|c|c|c|c|c|c|c}
\hline Total & 0,2083 & 0,1945 & 0,2082 & 0,2419 & 0,1461 & 0,2268 & 0,1736 & 0,2944 \\
\hline Sumber $:$.
\end{tabular}

Nilai IKT berdasarkan fungsi tanah untuk melestarikan aktivitas biologi ditunjukkan tabel 5 dan 6 diatas, dimana berkisar antara nilai $0,1461-0,3178$. Nilai IKT terendah terlihat di UL 13 di Kecamatan Ngluyu, sedangkan nilai IKT tertinggi terlihat di UL 2 di Kecamatan Bagor. Berdasarkan survei lapangan yang telah dilakukan memang terlihat Kecamatan Ngluyu merupakan kecamatan yang tandus dan gersang karena terbentuk dari bahan induk formasi kalibeng dan tambakromo. Sedangkan kondisi biofisik lahan di Kecamatan Bagor terlihat lebih subur seperti yang terlihat pada gambar dibawah:

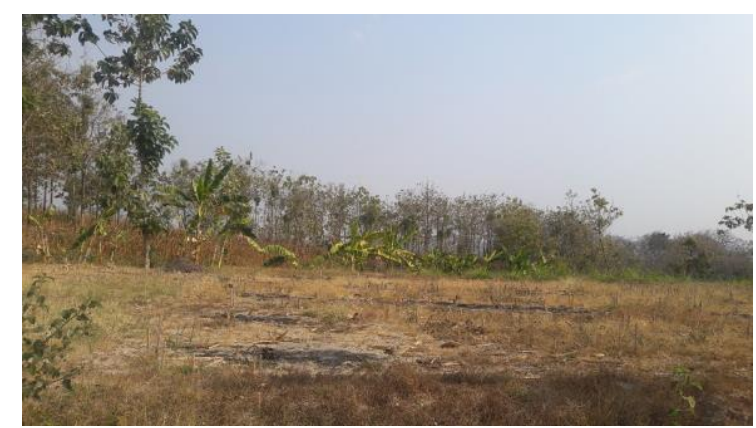

Gambar 2. Kondisi Biofisik Lahan di Kecamatan Ngluyu, Kabupaten Nganjuk

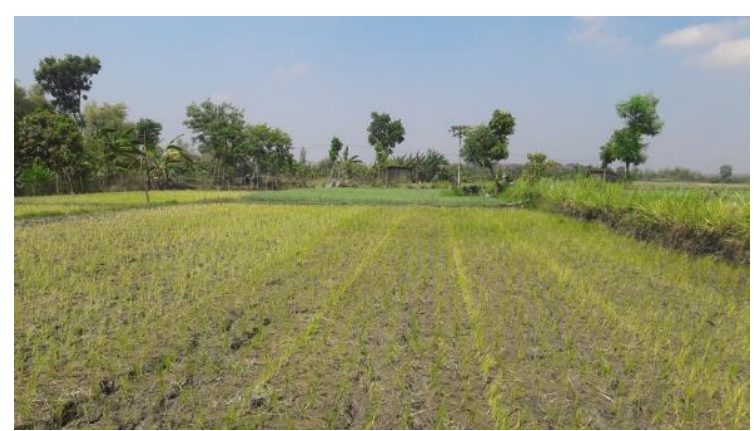

Gambar 3. Kondisi Biofisik Lahan di Kecamatan Bagor, Kabupaten Nganjuk

\subsubsection{Pengaturan dan Penyaluran Air}

Nilai IKT berdasarkan fungsi tanah sebagai pengaturan dan penyaluran air ditentukan berdasarkan 3 indikator yaitu prosentase debu dan liat, prosentase porositas tanah serta berat volume tanah. Hasil analisis menunjukkan nilai IKT terendah 0,0330 pada UL 14 di Kecamatan Ngluyu, dan nilai IKT tertinggi 0,3029 pada UL 12 di Kecamatan Ngetos. Fungsi tanah sebagai pengatur dan penyaluran air sangat penting apalagi dalam sektor pertanian. Tabel 7 dan 8 menunjukkan hasil analisis IKT di setiap unit lahan di Kabupaten Nganjuk.

Tabel 7. Hasil Analisis Indeks Kualitas Tanah Berdasarkan Fungsi Tanah sebagai Pengaturan dan Penyaluran Air

\begin{tabular}{l|c|c|c|c|c|c|c|c}
\hline \multirow{2}{*}{ Indikator Penilaian } & \multicolumn{7}{|c}{ Indeks Kualitas Tanah (IKT) } \\
\cline { 2 - 9 } & UL 1 & UL 2 & UL 3 & UL 4 & UL 5 & UL 6 & UL 7 & UL 8 \\
\hline Debu+liat & 0,0180 & 0,1920 & 0,0270 & 0,0060 & 0,0570 & 0,1920 & 0,2070 & 0,0210 \\
Porositas & 0,0083 & 0,0502 & 0,0111 & 0,0043 & 0,0207 & 0,0434 & 0,0532 & 0,0103 \\
Berat volume & 0,0210 & 0,0413 & 0,0158 & 0,0285 & 0,0180 & 0,0443 & 0,0353 & 0,0255 \\
\hline \multicolumn{1}{c}{ Total } & 0,0473 & 0,2834 & 0,0539 & 0,0388 & 0,0957 & 0,2797 & 0,2954 & 0,0568 \\
\hline
\end{tabular}

Sumber : Hasil Analisis (2020)

Tabel 8. Hasil Analisis Indeks Kualitas Tanah Berdasarkan Fungsi Tanah sebagai Pengaturan dan Penyaluran Air (lanjutan)

\begin{tabular}{l|c|c|c|c|c|c|c|c}
\hline \multirow{2}{*}{ Indikator Penilaian } & \multicolumn{7}{|c}{ Indeks Kualitas Tanah (IKT) } \\
\cline { 2 - 9 } & UL 9 & UL 10 & UL 11 & UL 12 & UL 13 & UL 14 & UL 15 & UL 16 \\
\hline Debu+liat & 0,0450 & 0,0000 & 0,0060 & 0,2100 & 0,0030 & 0,0030 & 0,0900 & 0,1830 \\
Porositas & 0,0078 & 0,0098 & 0,0081 & 0,0532 & 0,0072 & 0,0086 & 0,0157 & 0,0537 \\
Berat volume & 0,0240 & 0,0233 & 0,0233 & 0,0398 & 0,0210 & 0,0165 & 0,0255 & 0,0390 \\
\hline \multicolumn{1}{c}{ Total } & 0,0768 & 0,0330 & 0,0373 & 0,3029 & 0,0312 & 0,0281 & 0,1312 & 0,2757 \\
\hline
\end{tabular}

Sumber : Hasil Analisis (2020)

\subsubsection{Penyaring dan Penyangga}

Tabel 9 dan 10 memperlihatkan nilai indeks kualitas tanah berdasarkan dari fungsi tanah sebagai penyaring dan penyangga, semua unit lahan berada pada kisaran 0,0626 0,2694 dengan nilai paling rendah terdapat pada unit lahan 13 di Kecamatan Ngluyu dan tertinggi pada unit lahan 12 di Kecamatan Ngetos. Salah satu faktor yang sangat menentukan kualitas tanah sebagai penyaring dan penyangga adalah kandungan bahan organik tanah dangan didukung nilai porositas tanah. Kandungan bahan organik tanah (Corganik) unit lahan 12 dengan nilai IKT 0,0311 masuk kedalam kelas sedang dibanding dengan unit lahan yang lain, tapi karena didukung oleh porositas yang baik, nilai IKT di unit lahan 12 menjadi lebih baik dari unit lahan lainnya. Sehingga sifat kimia tanah yang 
didukung sifat fisik tanah yang baik akan

menghasilkan kualitas tanah yang lebih baik

Tabel 9. Hasil Analisis Indeks Kualitas Tanah Berdasarkan Fungsi Tanah sebagai Penyaring dan Penyangga

\begin{tabular}{|c|c|c|c|c|c|c|c|c|}
\hline \multirow{2}{*}{ Indikator Penilaian } & \multicolumn{8}{|c|}{ Indeks Kualitas Tanah (IKT) } \\
\hline & UL 1 & UL 2 & UL 3 & UL 4 & UL 5 & UL 6 & UL 7 & UL 8 \\
\hline Debu+liat & 0,0180 & 0,1920 & 0,0270 & 0,0060 & 0,0570 & 0,1920 & 0,2070 & 0,0210 \\
\hline $\begin{array}{l}\text { Porositas } \\
\text { Proses } \\
\text { mikrobiologis }\end{array}$ & 0,0041 & 0,0251 & 0,0056 & 0,0022 & 0,0103 & 0,0217 & 0,0266 & 0,0052 \\
\hline $\begin{array}{l}\text { C-Organik } \\
\mathrm{N} \text {-total }\end{array}$ & $\begin{array}{l}0,0224 \\
0,0441\end{array}$ & $\begin{array}{l}0,0462 \\
0,0026\end{array}$ & $\begin{array}{l}0,0327 \\
0,0456\end{array}$ & $\begin{array}{l}0,0314 \\
0,0450\end{array}$ & $\begin{array}{l}0,0263 \\
0,0448\end{array}$ & $\begin{array}{l}0,0436 \\
0,0023\end{array}$ & $\begin{array}{l}0,0229 \\
0,0006\end{array}$ & $\begin{array}{l}0,0285 \\
0,0443\end{array}$ \\
\hline Total & 0,0886 & 0,2659 & 0,1108 & 0,0845 & 0,1385 & 0,2596 & 0,2571 & 0,0989 \\
\hline
\end{tabular}

Sumber : Hasil Analisis (2020)

Tabel 10. Hasil Analisis Indeks Kualitas Tanah Berdasarkan Fungsi Tanah sebagai Penyaring dan Penyangga (lanjutan)

\begin{tabular}{l|c|c|c|c|c|c|c|c}
\hline \multirow{2}{*}{ Indikator Penilaian } & \multicolumn{7}{|c}{ Indeks Kualitas Tanah (IKT) } \\
\cline { 2 - 9 } & $\mathrm{UL} \mathrm{9}$ & $\mathrm{UL} \mathrm{10}$ & $\mathrm{UL} 11$ & $\mathrm{UL} 12$ & $\mathrm{UL} 13$ & $\mathrm{UL} 14$ & $\mathrm{UL} \mathrm{15}$ & $\mathrm{UL} 16$ \\
\hline $\begin{array}{l}\text { Debu+liat } \\
\text { Porositas }\end{array}$ & 0,0450 & 0,0000 & 0,0060 & 0,2100 & 0,0030 & 0,0030 & 0,0900 & 0,1830 \\
Proses mikrobiologis & 0,0039 & 0,0049 & 0,0040 & 0,0266 & 0,0036 & 0,0043 & 0,0079 & 0,0268 \\
$\quad$ & & & & & & & & \\
$\quad$ C-Organik & 0,0323 & 0,0341 & 0,0319 & 0,0311 & 0,0127 & 0,0387 & 0,0277 & 0,0308 \\
$\quad$ N-total & 0,0452 & 0,0456 & 0,0446 & 0,0017 & 0,0433 & 0,0456 & 0,0448 & 0,0008 \\
\hline \multicolumn{1}{c}{ Total } & 0,1264 & 0,0845 & 0,0866 & 0,2694 & 0,0626 & 0,0916 & 0,1704 & 0,2414 \\
\hline
\end{tabular}

Sumber : Hasil Analisis (2020)

\subsection{Nilai Indeks Kualitas Tanah dan Impikasinya dengan Degradasi Tanah}

Indikator kualitas tanah adalah sifat, karakteristik atau proses fisika, kimia dan biologi tanah yang dapat menggambarkan kondisi tanah (SQI, 2001). Menurut Doran \& Parkin (1994), indikator-indikator kualitas tanah harus (1) menunjukkan proses-proses yang terjadi dalam ekosistem, (2) memadukan sifat fisika tanah, kimia tanah dan proses biologi tanah, (3) dapat diterima oleh banyak pengguna dan dapat diterapkan di berbagai kondisi lahan, (4) peka terhadap berbagai keragaman pengelolaan tanah dan perubahan iklim, dan (5) apabila mungkin, sifat tersebut merupakan komponen yang biasa diamati pada data dasar tanah.

Berdasarkan kriteria kualitas tanah yang disusun Partoyo (2005) di Tabel 1, data kuantitatif pada Tabel 11 dan 12 dilakukan pengharkatan untuk mendapatkan kriteria kualitas tanah sesuai klas nilai indeks kualitas tanah (IKT) untuk masing-masing unit lahan di Kabupaten Nganjuk seperti ditampilkan pada Tabel 13.

Tabel 11. Hasil Analisis Pembobotan dan Penskoran Indikator Penilaian Berdasarkan Fungsi Tanah

\begin{tabular}{l|c|c|c|c|c|c|c|c}
\hline \multirow{2}{*}{ Fungsi Tanah } & \multicolumn{7}{c}{ Indeks Kualitas Tanah (IKT) } \\
\cline { 2 - 8 } & UL 1 & UL 2 & UL 3 & UL 4 & UL 5 & UL 6 & UL 7 & UL 8 \\
\hline $\begin{array}{l}\text { Melestarikan aktivitas } \\
\text { biologi }\end{array}$ & 0,1931 & 0,3178 & 0,2222 & 0,2080 & 0,2154 & 0,2688 & 0,2411 & 0,1893 \\
\hline $\begin{array}{l}\text { Pengaturan dan } \\
\text { penyaluran air }\end{array}$ & 0,0473 & 0,2834 & 0,0539 & 0,0388 & 0,0957 & 0,2797 & 0,2954 & 0,0568 \\
\hline Penyaring dan penyangga & 0,0886 & 0,2659 & 0,1108 & 0,0845 & 0,1385 & 0,2596 & 0,2571 & 0,0989 \\
\hline \multicolumn{1}{c}{ Total } & 0,3290 & 0,8671 & 0,3869 & 0,3314 & 0,4495 & 0,8081 & 0,7936 & 0,3451 \\
\hline
\end{tabular}

Sumber : Hasil Analisis (2020)

Tabel 12. Hasil Analisis Pembobotan dan Penskoran Indikator Penilaian Berdasarkan Fungsi Tanah (lanjutan)

\begin{tabular}{l|c|c|c|c|c|c|c|c}
\hline \multicolumn{1}{c|}{ Fungsi Tanah } & \multicolumn{9}{c|}{ Indeks Kualitas Tanah (IKT) } \\
\cline { 2 - 8 } & UL 9 & UL 10 & UL 11 & UL 12 & UL 13 & UL 14 & UL 15 & UL 16 \\
\hline $\begin{array}{l}\text { Melestarikan aktivitas } \\
\text { biologi }\end{array}$ & 0,2083 & 0,1945 & 0,2082 & 0,2419 & 0,1461 & 0,2268 & 0,1736 & 0,2944 \\
\hline $\begin{array}{l}\text { Pengaturan dan penyaluran } \\
\text { air }\end{array}$ & 0,0768 & 0,0330 & 0,0373 & 0,3029 & 0,0312 & 0,0281 & 0,1312 & 0,2757 \\
\hline Penyaring dan penyangga & 0,1264 & 0,0845 & 0,0866 & 0,2694 & 0,0626 & 0,0916 & 0,1704 & 0,2414 \\
\hline \multicolumn{1}{c}{ Total } & 0,4115 & 0,3121 & 0,3321 & 0,8142 & 0,2399 & 0,3464 & 0,4752 & 0,8115 \\
\hline
\end{tabular}

Sumber : Hasil Analisis (2020) 
Tabel 13. Kriteria Kualitas Tanah Berdasarkan Nilai Indeks kualitas tanah (IKT)

\begin{tabular}{c|c|c|c}
\hline No & $\begin{array}{c}\text { Unit Lahan } \\
(\text { UL) }\end{array}$ & Nilai IKT & $\begin{array}{c}\text { Kriteria Kualitas } \\
\text { Tanah }\end{array}$ \\
\hline 1 & UL 1 & 0,3290 & Rendah (R) \\
\hline 2 & UL 2 & 0,8671 & Sangat Baik (SB) \\
\hline 3 & UL 3 & 0,3869 & Rendah (R) \\
\hline 4 & UL 4 & 0,3314 & Rendah (R) \\
\hline 5 & UL 5 & 0,4495 & Sedang (S) \\
\hline 6 & UL 6 & 0,8081 & Sangat Baik (SB) \\
\hline 7 & UL 7 & 0,7936 & Baik (B) \\
\hline 8 & UL 8 & 0,3451 & Rendah (R) \\
\hline 9 & UL 9 & 0,4115 & Sedang (S) \\
\hline 10 & UL 10 & 0,3121 & Rendah (R) \\
\hline 11 & UL 11 & 0,3321 & Rendah (R) \\
\hline 12 & UL 12 & 0,8124 & Sangat Baik (SB) \\
\hline 13 & UL 13 & 0,2399 & Rendah (R) \\
\hline 14 & UL 14 & 0,3464 & Rendah (R) \\
\hline 15 & UL 15 & 0,4752 & Sedang (S) \\
\hline 16 & UL 16 & 0,8115 & Sangat Baik (SB) \\
\hline Sumber : Hasil Analisis $(2020)$ &
\end{tabular}

Sumber : Hasil Analisis (2020)

Hasil analisis kriteria kualitas tanah berdasarkan nilai indeks kualitas tanah di Kabupaten Nganjuk terlihat pada tabel 13. Kualitas tanah dengan nilai terendah di temukan pada UL 13 di Kecamatan Ngluyu dengan nilai IKT 0,2399, sedangkan kualitas lahan terbaik di temukan pada UL 2 di Kecamatan Bagor dengan nilai IKT 0,8671.

Parameter utama dalam penilaian kualitas tanah yang paling berpengaruh adalah kadar Corganik. Bahan organik dapat mengimmobilisasi bahan-bahan kimia buatan yang memberikan dampak merugikan terhadap pertumbuhan tanaman, membentuk komplek logam-logam berat, serta meningkatkan kapasitas sangga (buffer capacity) tanah (Nurmi, 2003 dalam Arifin, 2011). Dhaliwal et al (2019) juga menjelaskan C-organik tanah merupakan komponen terpenting dalam menjaga kualitas tanah karena perannya dalam meningkatkan sifat fisik, sifat kimia dan biologi tanah.

Kualitas tanah yang rendah akan berujung pada terjadinya degradasi tanah. Kowalska et al., (2018) menjelaskan sifat komprehensif dari penilaian kualitas tanah memungkinkan untuk estimasi risiko lingkungan, dengan penurunan kualitas yang terlihat sebagai akibat dari degradasi tanah.

Degradasi tanah dapat diartikan sebagai hilangnya kapasitas tanah untuk menyediakan jasa dan fungsi ekosistem (Ma et al., 2020; Lal, 2015). Hilangnya kapasitas retensi air karena berkurangnya porositas dan terlepasnya partikel tanah oleh erosi tanah, penurunan kolam $\mathrm{C}$ dan
$\mathrm{N}$, dalam kegiatan biomassa dan, akibatnya, dalam produktivitas pertanian, adalah salah satu masalah utama yang didorong oleh degradasi tanah (Ma et al., 2020). Dalam hal ini, perencanaan dan pengelolaan penggunaan lahan merupakan faktor kunci yang dapat mengurangi degradasi tanah (Orchard et al., 2013). Hal tersebut terkait dengan kualitas tanah yang hanya dapat dicapai jika dilakukan konservasi lahan yang meliputi pengelolaan biomassa, struktur tanah, penyimpanan air, siklus hara, aktivitas hayati dan keanekaragaman (Lal, 2004).

\section{KESIMPULAN}

Indeks kualitas tanah pada unit lahan di Kabupaten Nganjuk termasuk pada katagori "rendah" sampai "sangat baik" dengan kisaran nilai indeks kualitas tanah (IKT) $=0,2399-$ 0,8671 . Indeks kualitas tanah dengan kategori "rendah" dengan nilai terendah terdapat pada UL 13 di Kecamatan Ngluyu, sedangkan indeks kualitas tanah dengan kategori "sangat baik" dengan nilai tertinggi terlihat pada UL 2 di Kecamatan Bagor.

Persentase unit lahan yang mempunyai kualitas tanah kategori "rendah", "sedang", "baik", dan "sangat baik" berturut-turut sebesar $50 \%$, $18,75 \%, 6,25 \%$, dan $25 \%$. Dari hasil prosentase pada poin 3, terlihat sebagian besar unit lahan di Kabupaten Nganjuk rentan mengalami degradasi tanah.

Parameter utama penentu kualitas tanah di Kabupaten Nganjuk adalah kadar C-organik. Upaya rekomendasi yang dapat mengurangi degradasi tanah di Kabupaten Nganjuk antara lain:

a. Perencanaan dan pola pengelolaan penggunaan lahan.

b. Penambahan bahan organik berkala pada tanah-tanah yang mempunyai kualitas tanah rendah dan sedang.

c. Penggunaan bahan organik yang berbeda (misalnya residu tanaman, pupuk kandang dan bahan limbah) dikenal sebagai strategi yang efektif untuk meningkatkan efisiensi penggunaan hara dan kesuburan tanah

d. Pengurangan penggunaan pupuk-pupuk kimia pada lahan pertanian.

e. Meningkatkan biodeversitas vegetasi pada lahan pertanian atau perkebunan

f. Pencegahan erosi yang berlebihan, karena erosi yang menyebabkan terjadinya degradasi tanah.

\section{PERSANTUNAN}

Penulis mengucapkan terima kasih kepada Dr. M. llyas, M.Sc (Direktur PTRRB-BPPT), Bpk. 
Nur Hidayat, ST, MSi. (BPPT), Kepala Bappeda Kab. Nganjuk dan Bpk. Eko Wahyudi, (Bappeda Kab. Nganjuk). Ucapan terima kasih juga penulis sampaikan kepada rekan-rekan BPPT: Ir. Hasmana Soewandita M.Si, Qoriatu Zahro, S.Si, M.Sc., Ir. Heru Sri Naryanto, M. Sc, Ir. Wisyanto, MT sebagai bagian dari tim yang banyak membantu selama survei di lapangan, diskusi dan analisis data. Penelitian ini merupakan kerjasama penelitian antara PTRRB-BPPT dan Bappeda Kabupaten Nganjuk.

\section{DAFTAR PUSTAKA}

Agus, U., Rahmah Dewi Yustika, dan Umi Haryati. 2006. Penetapan Berat Volume Tanah. Sifat Fisik Tanah dan Metode Analisisnya. Balai Besar Litbang Sumberdaya Lahan Pertanian.

Arifin, Z., 2011. Analisis indeks kualitas tanah entisol pada pengguanaan tanah yang berbeda. Jurnal Agroteksos 21(1).

Bünemann, E.K., Bongiorno, G., Bai, Z., Creamer, R.E., De Deyn, G., de Goede, R., Fleskens, L., Geissen, V., Kuyper, T.W., Mäder, P., Pulleman, M., Sukkel, W., van Groenigen, J.W., Brussaard, L., 2018. Soil quality - A critical review. Soil Biol. Biochem.120 120, 105-125.

Dariah A., A. Rachman dan U. Kurnia. 2004. Erosi dan degradasi lahan kering di Indonesia. Dalam: Teknologi Konservasi Tanah Pada Lahan Kering Berlereng halaman:1-9. Pusat Penelitian dan Pengembangan Tanah dan Agroklimat. Bogor.

Dinas Pertanian Pemerintahan Kabupaten Nganjuk. 2019. Laporan Statistik Pertanian Tahun 2019.

Doran, JW. \& TB. Parkin, 1994. Defining and Assessing Soil Quality, In Defining Soil Quality for a Sustainable Environment. JW. Doran, DC. Coleman, DF. Bezdicek, \& BA. Stewart (eds). SSSA Spec. Pub. No. 35. Soil Sci. Soc. Am., Am. Soc. Agron., Madison, WI, pp.3-21.

Jocenei A.T. de Oliveira, Fabio A.M. Cássaro, Luiz F. Pires. 2020. Estimating soil porosity and pore size distribution changes due to wetting-drying cycles by morphometric image analysis, Soil and Tillage

Research. (http://www.sciencedirect.com/science/art icle/pii/S0167198720305961)

Karlen, D.L., M.J. Mausbach, J.W. Doran, R.G. Cline, R.F. Harris, and G.E. Schuman. 1997. Soil quality: A concept, definition, and framework for evaluation. Soil Science of America Journal 61: 4-10.
Kowalska, J.B., Mazurek, R., Gasiorek, M., Zaleski, T., 2018. Pollution indices as useful tools for the comprehensive evaluation of the degree of soil contamination-a review. Environ. Geochem. Health https://doi.org/10.1007/s10653-018-0106$z$.

Kurnia, U., N. Sutrisno, dan I. Sungkawa. 2010. Perkembangan lahan kritis. Dalam Membalik Kecenderungan Degradasi Sumbnerdaya Lahan dan Air. IPB PRESS. Bogor.

Lal, R., 2004. Soil carbon sequestration impacts on global climate change and food security. Science 80. https://doi.org/10.1126/science.1097396.

Lal, R., 2015. Restoring soil quality to mitigate soil degradation. Sustainability $7,5875-$ 5895. https://doi.org/10.3390/su7055875.

Liu Z, W. Zhou, J. Shen, S. Li, G. Liang, X. Wang, J. Sun, and C. Ai. 2014. Soil quality assessment of acid sulfate paddy soil with different productivities in Guangdong province, China. Journal of Integrative Agriculture 13: 177-186.

Ma, X., Asano, M., Tamura, K., Zhao, R., Nakatsuka, H., Wuyunna, Wang, T., 2020. Physicochemical properties and micromorphology of degraded alpine meadow soils in the Eastern QinghaiTibet Plateau. Catena 194, 104649. https://doi.org/10.1016/j.catena.2020.104 649.

Mausbach, M.J., and C.A. Seybold. 1998. Assessment of Soil Quality. In Soil Quality and Agricultural Sustainability. Ann Arbor Press. Chelsea. Michigan.

Orchard, C.M., Lorentz, S.A., Jewitt, G.P.W., Chaplot, V.A.M., 2013. Spatial and temporal variations of overland flow during rainfall events and in relation to catchment conditions. Hydrol. Process. 27, 2325-2338. https://doi.org/10.1002/hyp.9217.

Partoyo. 2005. Analisis indeks kualitas tanah pertanian di lahan pasir Pantai Samas Yogyakarta. Jurnal IImu Pertanian 12: 140-151.

S.S. Dhaliwal, R.K. Naresh, Agniva Mandal, Ravinder Singh, M.K. Dhaliwal. 2019. Dynamics and transformations of micronutrients in agricultural soils as influenced by organic matter build-up: A review, Environmental and Sustainability Indicators, Volumes 1-2. (http://www.sciencedirect.com/science/art icle/pii/S2665972719300078)

Shrestha, D.P. 1995. Land degradation assessment in a GIS and evaluation of 
remote sensing data integration. International Institute For Aerospace Suvey and Earth Science (ITC), Enschede, The Netherlands.

Singer, M.J. and D.N. Munns. 2006. Soil Degradation. Sixth Edition. Pp 354-384. In D. Yarnell, M.Rego,A.B. Wolf (Eds.) Soils an Introduction. Pearson Prentice Hall.

Sitorus, S., B. Susanto dan O. Haridjaja. 2011. Kriteria dan klasifikasi tingkat degrdasi lahan. Jurnal Tanah dan Iklim No.34 Desember 2011. HIm 66-83. Balai Besar Litbang Sumberdaya Lahan Pertanian. Bogor.

Soil Quality Institute (SQI). 2001. Guidelines for Soil Quality Assessment in Conservation Planning. Soil Quality Institute. Natural Resources Consevation Service. USDA.

Statistik Daerah Kabupaten Nganjuk. 2019. Badan Pusat Statistik Kabupaten Nganjuk.

https://nganjukkab.bps.go.id/publication/d ownload.html?nrbvfeve=MDJjMGE5OTNj NDEwZjBhNmUwZjFjY2Nj\&xzmn=aHROc HM6Ly9uZ2FuanVra2FiLmJwcy5nby5pZ C9wdWJsaWNhdGlvbi8yMDE5LzExLzA2 LzAyYzBhOTkzYzQxMGYwYTZIMGYxY 2NjYy9zdGF0aXNOaWstZGFIcmFoLWth YnVwYXRIbi1uZ2FuanVrLTIwMTkuaHRt $\mathrm{bA} \% 3 \mathrm{D} \% 3 \mathrm{D} \&$ twoadfnoarfeauf=MjAyMC0 xMi0xNiAxMDozNjoxNQ\%3D\%3D.

Wahyunto dan Ai Dariah. 2014. Degradasi Lahan di Indonesia: Kondisi Existing, Karakteristik, dan Penyeragaman Definisi Mendukung Gerakan Menuju Satu Peta. Jurnal Sumberdaya Lahan Vol. 8 No. 2,Desember 2014;81-93. 